\section{Portland Cement Industry of the United States}

Stamistics relating to the Portland cement industry of the United States, compiled by the U.S. Bureau of Mines, show that the quantity of this substance produced in 1940 was $130,216,511$ barrels (the unit of measure employed throughout the statistics is the barrel of $376 \mathrm{lb}$.). The output for 1940 is not only 7 per cent higher than the output for 1939 but also was the largest quantity manufactured since 1930. Nevertheless, the output for 1940 was less by 20 per cent than that for 1928, which still constitutes the peak year of production. Basing their figures on the quantities of cement dispatched from works into the various States of the Union, aggregating nearly $127,800,600$ barrels, it is estimated that the annual per capita consumption of cement averaged 0.96 barrel (about 3 cwt.) in the whole of the United States in 1940, as compared with 0.94 barrel in 1939. These figures represent only the records of the consignments inside the country. During $1940,80.9$ per cent of the Portland cement dispatched from works in the United States was moved by railway, $15 \cdot 6$ per cent by motor lorry and $\mathbf{2 \cdot 2}$ per cent by boat. Furthermore, 25.6 per cent of the cement was dispatched loose, in bulk, 42.4 per cent was packed in paper bags, 31.9 per cent in eloth bags, and 0.1 per cent in other containers, including steel drums and iron or wooden barrels.

Imports of hydraulic cements into the U.S. in 1940 totalled 91,000 tons, compared with 321,000 tons in 1939. In both years the chief supplying country was Belgium and the second was Denmark. In spite of its large annual cement production, the export trade of the United States is small, totalling in 1940 a little more than 1 per cent of the production. The exports for 1940, however, which totalled nearly 284,000 tons, were higher than in any other recent year. Of the 1940 exports, 206,000 tons were dispatched to various countries on the North American Continent, the Central American Republics, the West Indies and Canada. The largest quantity was consigned to the Panama Canal Zone, namely, 82,000 tons. According to Engineering of September 26, South American countries imported in 1940, 73,400 tons of cement from the United States, Europe merely 76 tons, Asia 1,320 tons, Africa 2,390 tons and Oceania 70 tons ; 248,500 tons of cement were shipped to Alaska, Hawaii, Puerto Rico and other outlying territories of the United States.

\section{Animal Production and Veterinary Science Abstracts}

To meet the requirements of those engaged in the animal industries, a new section of Biological $A b$ stracts, to be known as "Section F, Abstracts of Animal Production and Veterinary Science", will begin in January next. It will contain all the abstracts published in Biological Abstracts that have to do with the breeding, nutrition and metabolism, husbandry, reproductive and other physiology, anatomy, pathology and parasitology, and arthropod pests of livestock, poultry and semi-domesticated animals and birds, including pet stock. The new section will consist of ten abstract issues a year.
The annual subscription rate will be 5 dollars, and subscribers will receive the index to the complete edition of Biological Abstracts. Biological Abstracts now covers some 1,450 periodicals, so the new section will, from the beginning, afford a very complete survey of the biological literature pertaining to the animal industries. Inquiries should be addressed to Biological Abstracts, University of Pennsylvania, Philadelphia.

\section{Announcements}

Prof. Emtle Picard, For. Mem. R.S., permanent secretary of the Paris Academy of Sciences and a distinguished mathematician, died on December 12, aged eighty-five.

The Symons Gold Medal for 1942 of the Royal Meteorological Society has been awarded to the late Dr. J. S. Owens, whose death occurred on December 6. This Medal is awarded biennially for distinguished work in connexion with meteorological science. The presentation will be made at the annual general meeting of the Society on January 21 next.

DR. R. B. McConnell, assistant field geologist, has been appointed geologist of the Lands and Mines Department, Tanganyika.

Dr. Orlando Park, Northwestem University, will in future edit the "General Animal Ecology" Section in Biological Abstracts, thus succeeding Dr. W. C. Allee. The "Speciation" Seetion will be edited by Dr. Alfred Emerson, of the University of Chicago.

ThE title of professor emeritus of logic and scientific method in the University of London has been conferred on Dr. A. Wolf, on his retirement from the professorship of logic and scientific method at University College and the London School of Economics.

Prof. Hermann Steudec, emeritus professor and director of the Institute of Chemical Physiology at Berlin, has been awarded the Goethe Medal for Art and Science on the occasion of his seventieth birthday.

The Financial Secretary to the Treasury stated on December 11 in reply to a question in the House of Commons that the number of students at universities and university colleges in Great Britain during the past autumn was approximately 25,000, of whom 5,900 were grouped as taking arts subjects and 19,100 scientific, technical and medical subjects.

Mr. R. J. Funntoff, of Goathland, Yorks, founder of the Northern Ecological Society (see Nature, December 13, p. 722) bequeathed his notebooks on plants to the British Museum ; $£ 1,000$ to the Linnean Society of London for a medal; $£ 1,000$ to the Chemical Society for a medal; and $£ 1,000$ to the University of Manchester for a prize; he also made provision for the publication of his researches. 